\title{
PENAL MEDIATION FROM A PERSPECTIVE OF SOCIAL CONTROL. FRENCH AND SPANISH EXPERIENCES
}

\section{G. PALERMO}

\section{Giovanna PALERMO, PhD}

Researcher in legal sociology, deviance and social change

Cassation lawyer

Secretary General of the Cuam University Foundation

Department of Psychology

University of Campania Luigi Vanvitelli, Italy

Mail address:Giovanna Palermo, Agora University of Oradea, 8 Piaţa Tineretului St., Oradea, Romania

E-mail: giovanna.palermo@unicampania.it

\section{ABSTRACT}

This research is focused on the penal mediation that is resorted in social, educational, family, cultural, criminal and other conflicts, in order to obtain recognition not only in terms of otherness, but above all of collective belonging. The article presents cases of mediation in France and in Spain. The main idea is that mediation can be used in all the systems in which the conflictual dynamics are manifested.

KEYWORDS: penal mediation, social control, conflict, criminal law

\section{INTRODUCTION.}

The age of globalization, in the second and third phase (the second already ended with the twentieth century), in which we witness the full deployment of the productive and commercial potentialities of humanity, has broken the "boundaries" of the relationship between individual and institutions, spreading a feeling of "disorientation", fueled by the widespread complexity of heterogeneous and sometimes contradictory values.

In the society of individualism the collective forms of control must give way to individual and individualized forms, which go to work on the individual.

Often they are tools that exist or are born in the social, disconnected from the institutional network and aimed at helping people to manage the relational conflicts that enmesh them. In this context the mediation, precisely because it is born as experience and social practice and constitutes an adequate response to the needs of the individual, it can represent a new (at least for the right) and different modality conflict regulation, which allows institutions to move closer to the individual, recovering the dual capacity and function of promoting individual liberties and guaranteeing social order.

\section{THE CRISIS OF INSTITUTIONS AND THE MEDIATION AS AN ALTERNATIVE TOOL OF CONFLICT MANAGEMENT}

The crisis of institutions and the consolidation of individualism, the widespread lability of consciences and the common indifference towards the "set of values, norms, customs that with varying effectiveness define and regulate durably, regardless of the identity 


\section{Giovanna Palermo}

of individual people" (Gallino, 1993, 387) find their incompressible and ineluctable causality in the social, economic and cultural change of our day.

The age of globalization, in the second and third phase (the second already ended with the twentieth century), in which we witness the full deployment of the productive and commercial potentialities of humanity, has broken the "boundaries" of the relationship between individual and institutions, spreading a feeling of "disorientation", fueled by the widespread complexity of heterogeneous and sometimes contradictory values.

The institutions, that is all those systems that have "a general regulatory value", assume legitimacy if they are functional to the concrete reality of civil society and consistent and adhering to collective needs. When they are unable to listen to these needs and give an adequate response, the individual moves away from the institutions and these, consequently, lose legitimacy.

The detachment of the individual from the institutions favors that crisis of which so much is spoken and the need to seek tools and forms that they can allow to re-establish the relationship also in order to avoid a definitive and total delegitimization.

The individual no longer recognizes institutions as their derivations, capable of guaranteeing and protecting them, credible and reliable; equally the rules appear empty and betray the trust and the desire for recognition and protection of everyone. The norm does not satisfy!

Hence the diaspora towards areas increasingly on the margins of legality.

The conscious vision of the individual-institution relationship crisis reveals the need to look for tools that favor a path of recovery of the bond, of the sense of trust, of guarantee and of credibility.

For this reason, and to block the de-legitimization process,

the need to support the formal regulatory control ${ }^{1}$ (Ross) a "soft" control emerges, with tools that allow to create an interaction with the citizen, making him feel closer to the institutions, in a new perspective capable of living and operating horizontally.

The research is therefore aimed at the re-discovery of means that "look after" the citizens, their problems, their conflicts (big and small) and that help them, in this way, to obtain recognition not only in terms of otherness, but above all of collective belonging.

In the society of individualism the collective forms of control must give way to individual and individualized forms, which go to work on the individual.

Often they are tools that exist or are born in the social, disconnected from the institutional network and aimed at helping people to manage the relational conflicts that enmesh them. In this context the mediation, precisely because it is born as experience and social practice and constitutes an adequate response to the needs of the individual, it can represent a new (at least for the right) and different modality conflict regulation, which allows institutions to move closer to the individual, recovering the dual capacity and function of promoting individual liberties and guaranteeing social order.

With institutionalized mediation, a process of control of social relations is started no longer in terms of imposition, but of interaction. «Two ideologies currently dominate the

\footnotetext{
${ }^{1}$ The distinction between regulatory operating institutions was introduced by Ross in 1901: operating institutions implement a service to society or a part of it (business, administrative organs of the state, hospitals, schools);regulative institutions, however, have as their main function the control of forms of behavior through the definition of models to follow.
} 


\section{PENAL MEDIATION FROM A PERSPECTIVE OF SOCIAL CONTROL. FRENCH AND SPANISH EXPERIENCES}

mediation discourse - individualistic and relational. An individualist view, upon which the settlement approach is based, sees the world as made up of separate beings of equal worth, but different needs, whose human nature it is to seek satisfaction of their needs and desires. A relational framework, views the world as made up of persons with diverse needs and desires but who possess a common form of consciousness that connects them to each other. Transformative models of mediation are based on this ideology (Bush and Folger, 1994). (Picard A. C., 2000)

Mediation, conducted by a third and unknow subject, is a process that aims to open channels of communication that were blocked, allowing the parties in conflict to compare their points of view and find a solution to the problem.

Mediation, as an tool for managing conflicts expressed and unexpressed, shows the need to overcome them, avoiding pathological interpretations of the conflict and, instead, reworking the critical event in terms of relational reorganization, rediscovering other communication plans.

In this way, broken the logic of the conflict and interrupted its escalation, it is possible to reach an agreement, deeply and emotionally matured and, therefore, more stable and lasting than any executive decision.

Conceived as a resource for an informal management of the conflict between two people in terms of re-discovery and mutual re-know, mediation assumes the value of an tool that can be used in all the systems in which the conflictual dynamics are manifested, albeit with the necessary peculiarities and specificities that the different contexts require.

So we could resort to mediation in social, educational, family, cultural, criminal and other conflicts.

In particular, the commission of a crime produces or feeds a conflict, a communicative fracture between the victim and the guilty party, which sees the victim unrecognized and not respected as a person and often relegated to his marginal and unsatisfactory trial role; the guilty, isolated and subjected to a process of labeling, which will make him a career criminal.

A path of mediation in this context would build a "space" and a "time" that could favor the recovery of roles in the conflict, giving the victim a central and recognized position and favoring the rapprochement with socially shared values.

In this perspective, mediation favors both a "re-education" of the guilty, an aware recognition of the rules and social relations, and the possibility for the victim to assume ownership in the management of the conflict and to be recognized as a person, with all his suffering.

The deepest motivation that pushed us to look for ways to integrate the process is in the awareness of the inadequacy and incompleteness of this process and in the need to recognize to the passive subject of the crime a role that the criminal trial does not guarantee: the centrality and priority in regulating the conflict arising from the crime.

Mediation, therefore, arises as a possible response to these needs, as an instrument through which "re-establish a broken relationship between several parties and not, unlike the jurisdictional act, to establish a winner and a loser, a reason and a wrong " (Bouchard, 1995).

As an tool of non-violent regulation of the conflict, inspired by logics and communication and emotional dynamics, mediation favors a real informal path of

management of the conflict between victim and offender through recognition and 


\section{Giovanna Palermo}

the identification with the other and with his feelings.

The penal mediation, therefore, is essentially a process of relating two people and goes to work, as Woolpert (Woolpert, cit. in Mackay R., 1992), on three levels:

- as a process aimed at encouraging personal awareness;

- as an tool aimed at increasing the self-esteem of the victims and the sense of responsibility of the offenders;

- as an intervention aimed at promoting the sense of belonging to the community.

From a structural point of view the mediation is an informal path punctuated by different phases, during which the mediator, the equidistant third party, promotes communication among the conflicting, fostering confrontation, recognition of the other as a person, with his fears and emotions, to come to an agreement for conflict management.

It is, therefore, a modality of intervention that aims to "enter the conflict", helping the parties to meet, to understand their behavior and, if possible, to agree on solutions.

This way of regulating conflicts does not replace the trial, but it can well represent, in an exosystemic vision, an operational asset, usable for a management of the conflict in its complexity, which takes into account not only the declared conflict but also that conflictual level that has not been manifested and of which the "trial" does not take into account.

Furthermore, the criminal trial ends up denying recognition to the victim, forced to relive the offense suffered for a long time, often subject to attempts to blame, with the risk of not even get a repair at the end. The criminal trial can protect the guilty and at the same time stigmatize him.

This model of justice has as its objective the elimination of the negative effects of the crime, through a process of recognition and self-esteem on the one hand and of responsibility on the other, also through restoring the damage by the offender.

The offender is no longer a passive subject recipient of a penalty, but an active subject who is asked to remedy the errors made and the damage caused by his criminal conduct. From criminological perspective, importance is attached to lying testimonies that bring justice service $^{2}$

Expression of the reparative paradigm, the mediation involves the victim, the offender and the community in the search for solutions to the effects of the conflict generated or fed by the crime, with the aim of promoting compesation for the damages, reconciliation between the parties and the strengthening of the collective sense of security. Through the "restorative" the victim can regain control over his life and his emotions, gradually overcoming the feelings of revenge, rancor and even of mistrust and its inevitable paralyzing effects.

The offender, for his part, is not only the passive subject receiving the penalty; but an active party who is asked to remedy the errors made and the damage caused by his criminal conduct.

Mediation, with its pervasive capacity, exerting a deterrent and accountable function, already represents a new way of regulating and controlling conflict.

The need to rectify the crisis of legitimization of the penal institutions, which more generally reflects the crisis of the mechanisms of social regulation, tries to go through the attempt of the law to incorporate the mediation and link it to the criminal trial.

\footnotetext{
${ }^{2}$ Elena-Ana Nechita, Criminalistică. Tehnica si tactica criminalsitică, PRO Universitaria, Bucharest, 2009, p.163
} 


\section{PENAL MEDIATION FROM A PERSPECTIVE OF SOCIAL CONTROL. FRENCH AND SPANISH EXPERIENCES}

Conflicts destabilize the community and the inability of the state institutions to manage them determines, as we have already pointed out, their progressive delegitimization, a loss of credibility and an inevitable moving away from the community.

The institutions are no longer able to respond adequately to the needs of the individual, for which he begins to no longer recognize them, to not consider them credible, to delegitimize them. The institutions, as a result of this distancing of the individual and this progressive delegitimization, which will end up rendering them useless and emptied of power, seeks exogenous tools that, moving on a horizontal plane, are able to be close to the needs of the individual. and to give satisfactory answers. They absorb them in their mechanisms, make them their own. Thus the institutions and in particular the judicial universe can give an adequate response to the individual.

One of these tools is the mediation that is open to this logic, precisely because of its ability to informally manage conflicts, restoring the ownership, in the search for the solution, to the parties.

Mediation is in itself an tool through which an informal control over individuals is exercised and its institutionalization responds not so much and not only to the institutional need for control, but rather to the need to recover credibility and reliability in the eyes of individuals.

Including mediation in criminal law, and in particular in the judicial universe, responds to the logic of regaining legitimacy. The penal system, in fact, is a system that for its characteristics, its rituals, its language, tends to isolate itself, producing a block of communication and interpretation, a separation with other systems, first of all the social one. This closure and distance delegitimizes the law, depriving it of its concrete foundation.

In the face of this crisis of legitimacy of criminal law and its inability to meet the needs of each individual, the community is organized by developing alternative tools of conflict management that, on the one hand, heighten the crisis of law and, on the other, tend to increase the power of the social system to function autonomously.

The weakening of expectations towards formal control tend to increase the space of informal control.

The attempt to institutionalize mediation expresses the desire for law and, therefore, for the judicial universe to absorb it to rediscover or recreate a new systemic balance and recover legitimacy, with a view to re-establishing an individual-institution interaction, to exercise control over individuals, their conflicts, on how to manage them and on the social risks of these conflicts, with a view to recovering and strengthening its legitimacy. Mediation is open to this end because it expresses the desire and the will to deform the management procedures with a view to restoring the ownership of the conflict and its "solution" to the parties involved.

\section{MEDIATION IN THE CRIMINAL FIELD IN FRANCE AND SPAIN}

One of the risks of the incorporation of mediation in the judicial universe is the loss of that promotional character of the private autonomy that characterizes it, to become a "reward" 


\section{Giovanna Palermo}

if it has a positive outcome or a "threat" if the parties do not consent to participate in the mediation path or if this fails. ${ }^{3}$

Let's think, for example, of what happened in France, where the first attempts to absorb mediation went through the granting of funding to organizations of victims who were more dealed with mediation, then arriving in October 1992 at the Ministry of Justice, which spread a guidance note on penal mediation, up to the full institutionalization made by the reform law of the code of criminal procedure of 04/01/1993.

In Article. 6, integrative of the art. 41 of the Code of Criminal Procedure, the Public Prosecutor was expressly authorized to decide, after a preliminary agreement with the parties to use the mediation, with the aim of ensuring the restoring the damage to the victim, to end the conflict and to contribute to the reintegration of the auteur des faits. In fact, the successful outcome of the mediation, which ends with a written agreement, is cause for dismissal the case by the public prosecutor.

The French experience dates back, however, to 1980, the period in which some districts of Lyon were beginning to rise, c.d. "Boutiques de droit" which, according to their main inspirer (Bonafé-Schimitt), already made social mediation.

These emphasize the need to reconstruct spheres of sociality in places where the tearing of the social fabric is most evident (degraded neighborhoods, etc.) and the failure of traditional ways of regulating conflict appears to be greater.

The Boutiques de droit identify in their neighborhood the most suitable place in which everyday conflicts can be institutionalized and regulated. This attention to the conditions of degradation rather than to the techniques of conflict resolution represents the characteristic and, at the same time, the limit of the Lyon project.

In fact, the social contextualization of the conflict, which widens the attention to the satisfaction of broader social policies, runs the risk of not opportunely focusing the recomposition of the single conflict.

The boutiques also have the task of "mediation / knowledge", inform the user about all the tools he has available to resolve his disputes, and including the mediation itself.

By virtue of this link between legal information and mediation, the cases taken into consideration by the boutiques come from the community and not from the transmission of the notification by the judicial authorities. In Spain, informal experimentation mediation has also become an integral part of the criminal trial.

The first experiences of mediation were carried out in Catalonia, where a commission was set up in 1989 within the Justice Department of the Generalitat of Catalonia, regional government body, with the task of drafting a juvenile criminal mediation project and in May 1990 the mediation program began to function in Catalonia for crimes committed by minors, although it was not provided for by the law in force, the law of 11 June 1948 of the juvenile court ${ }^{4}$.

\footnotetext{
${ }^{3}$ When the mediation is inserted in the judicial process as a normative instrument, in fact, if the parties consent to start this path and in that place they reach agreement, the law reward them, eg. with the dismissal, the mitigating circumstances, etc .; if, instead, the parties do not want to go to mediation or if it fails, the law punishes them or threatens to punish them.

${ }_{4}$ This law was issued under the Franco regime and sanctioned even purely irregular behavior by all those aged between 0 and 16 years. Even with its limitations and its provisional nature (it had to remain in force for 1 year), it had the merit of having determined the passage from a positivist and correctionist model (which inspired the 1948 law) to a guaranteeing and empowering model.
} 


\section{PENAL MEDIATION FROM A PERSPECTIVE OF SOCIAL CONTROL. FRENCH AND SPANISH EXPERIENCES}

The normative support of this choice was then identified in the recommendations of the Council of Europe, in the laws of other European countries, in the United Nations Minimum Rules on the Administration of Justice and in the United Nations Convention on the Rights of the Child.

The major obstacle that the mediation encountered in entering the juvenile criminal trial arose from the necessity of the consent of the two parties and the 1948 law considered the children of 16 years not imputable and, therefore, unable to give consent to participate in a path of mediation. For this reason the judge had to give it in their place.

From 1990 to 1992, about 1200 cases were dealt with by mediation.

Subsequently, under the guise of "urgent" reform dictated by the declaration of unconstitutionality of art. $15^{5}$ of the 1948 Act (sentence 36/91), the law 5 June 1992 n. 4 was enacted, which modified only some articles of the law of '48, causing contradictions in the new text.

The new law introduced some fundamental characteristic principles to protect the minor. First of all, the principle of the best interests of the child, which involved respect for the personality of the child and its development processes. Therefore, the measures to be applied had to respect the educational needs ${ }^{6}$ of the minor and the whole process had to respond to pedagogical and punitive purposes ${ }^{7}$.

Another fundamental principle introduced was that of the minimum intervention, to be applied not only during the trial but above all as an instrument to favor the decriminalization of deviant behavior. This principle provides that the court has "wide powers to agree the end of the trial to avoid, as far as possible, the afflictive effects that it can produce to the minor". Thus on the one hand it gives to the public prosecutor

the possibility of not pursuing certain crimes if accompanied by certain circumstances, such as the lack of seriousness of the facts, and from the other to the juvenile court, therefore, the power to dismiss the case or decide to suspend, for a fixed term, of the sentence.

For the first time, moreover, the law introduced in Spain the so-called "Principio de oportunidad" 8 , by virtue of which, before a crime report, the public prosecutor could, if necessary, decide freely in favor of criminal prosecution without any kind of control.

Precisely in the name of this principle ${ }^{9}$ the mediation was introduced, as a path that, ending with the reparation of the damage ${ }^{10}$, gave the fiscal ministry a valid reason for not to prosecute.

\footnotetext{
${ }^{5}$ Article 15 reads: "the sessions that the tutelary tribunals celebrate are not public and the court is not subject to the rules of procedure in force in other jurisdictions". Therefore, it excluded the application of the procedural rules in force in other jurisdictions to the juvenile criminal trial (it involved the non-application of the guarantees of the ordinary process to that for minors, where neither the defense lawyer nor the public prosecutor intervened).

${ }^{6}$ In this regard, the intervention of a technical group was planned with the task of reporting on the child's psychological, educational and family situation as well as on environmental conditions.

${ }^{7}$ In this direction, for example, the suspension of the trial and the extrajudicial reparation of the damage were foreseen when the further course of the proceeding had adversely affected the educational needs of the minor.

${ }^{8}$ The principle of opportunity is also provided for in international legislation. In this regard, article 11.2 of the Beijing Rules reads "the police, the prosecutor or other services in charge of juvenile delinquency will have the power to decide such cases at their discretion, without resorting to formal proceedings, in accordance with the criteria set for this purpose in the respective legal systems, and also in harmony with the principles contained in these rules ".
} 


\section{Giovanna Palermo}

The process of mediation, aimed at repairing the damage, was also conceivable at a later date, as an alternative to the execution of the measure established by the judge in the sentence $^{11}$. In this case, the suspension of the sentence was therefore functional to the implementation of the reparation: if, in fact, the reparation had not been completed, the judge would have implemented the sentence. The law in question canceled the absolute discretion of juvenile jurisdiction, recognizing for the first time the constitutional guarantees, in a perspective aimed at re-educating the minor.

Even with its limits and its temporary nature he had the great merit of determining the transition from one positivist and correctionist model (which inspired the 1948 law) to another guarantor, empowering and aimed at the re-education of the minor, in accordance with the Council of Europe recommendations.

On January 1, 2001 the law of 12 January 2000 no. 5 on the criminal responsibility of the minor entered into force (a law that for the first time deals with juvenile justice in an overall way containing rules of substantive law, procedural law and penitentiary), in which explicit reference is made to mediation and there is also talk of reconciliation and reparation of damage. The Organic Ley of 12 January 2000 n. $5^{12}$ (LORP), in regulating the criminal liability of minors ${ }^{13}$, has foreseen the need to take to account not only the interests of the minor offender, but also of the victim, both in judicial processes and in extrajudicial matters.

For the first time in Spanish legal history, "the functions of mediation" and the cd. "Indirect mediation" are expressly explicitly covered.

The new law provides, in fact, the possibility of access to mediation at two different stages of the criminal proceedings, that is during the preliminary examination phase, and during the execution of the judgment.

In the preliminary examination phase, article 19.2, entitled "Dismissal of the case for conciliation or reparation between the child and the victim", defines what is meant by conciliation and reparation and the benefits that may arise from it. In particular, the second paragraph, as amended by the L.O. 8/2006, of 4 December 2006 provides that "A efectos de lo dispuesto en el apartado anterior, se entenderá producida la conciliación cuando el menor reconozca el daño causado y se disculpe ante la víctima, y ésta acepte sus disculpas, y se

\footnotetext{
${ }^{9}$ Article. 15.6 of the aforementioned law provided, in fact, that during the preliminary investigation "considering the lack of seriousness of the facts, the conditions and circumstances of the minor, the fact that there had been no violence or intimidation, or that the minor had repaired or committed to repair the damage caused to the victim, the judge, on the proposal of the public prosecutor, will close every action".

${ }^{10}$ The possibility of repairing the victim's damage was foreseen for the first time by Law n.4 / 1992.

${ }^{11}$ Article 16.3 of the law provided that "having regard to the nature of the facts, the juvenile judge, ex officio or at the request of the public prosecutor or lawyer, could assess the suspension of the decision for a fixed period of up to two years, always that, by mutual agreement, the child, duly assisted, and the victims, accepted an out-ofcourt redress proposal. This opportunity may be granted if the victims, duly cited, do not express their opposition or are manifestly unfounded. To this end, after hearing the technical group, the public prosecutor and the lawyer, the judge must reasonably evaluate, from the exclusive point of view of the minor's interest, the pedagogical and educational meaning of the proposed reparation [...]. does not carry out the repair will revoke the suspension of the sentence and will complete the measure established by the judge ".

${ }^{12}$ In the reform on civil and mercantile mediation, introduced by the Organic Law 5/2012, Articles 6.1, 6.3, 7, 8, $10.1,10.3,11,12,13,14,17,18,19$ were also extended to penal mediation. The first articles, in particular, establish the general principles that apply to all types of mediation: voluntariness, equality of the parties and impartiality of the mediator, neutrality, confidentiality, secrecy and gratuity.

13 While the 1. 4/92 took care of children aged twelve to sixteen, the law 5/2000 is intended to be applied to minors from fourteen to eighteen.
} 


\section{PENAL MEDIATION FROM A PERSPECTIVE OF SOCIAL CONTROL. FRENCH AND SPANISH EXPERIENCES}

entenderá por reparación el compromiso asumido por el menor con la víctima o perjudicado de realizar determinadas acciones en beneficio de aquéllos o de la comunidad, seguido de su realización efectiva. Todo ello sin perjuicio del acuerdo al que hayan llegado las partes en relación con la responsabilidad civil”.

The provision provides the extra-judicial way to resolve the conflict through the path of conciliation, reparation and criminal mediation.

In order to determine this spill of the minor from the juvenile criminal trial the following requirements must be met ${ }^{14}$ : the lack of violence or serious intimidation in the facts and whether it is a less serious crime or a violation; the recognition by the minor of a "certain participation" in the deeds constituting a crime; the proposal by the technical group of a mediation project accepted by the minor and the victim; the actual realization of the repairing or mediating activity by the minor.

The fulfillment by the minor of the repairing activity will make void the criminal responsibility with consequent dismissal of all charges . Particular features of the provision in question is the provision of so-called "indirect mediation", in which there is no meeting between the victim and the offender.

The art 19.4 provides, in fact, the particular case in which, for reasons unrelated to the will of the minor offender, conciliation or realizing the reparation obligations towards the victim is not possible. These are the hypotheses in which, for example, you have not been able to contact the victim (because you do not know or do not respond to letters or telephone calls) or the victim does not want to participate. In these cases, the child's will to repair the victim can avoid his entry into the criminal trial.

The conciliation of the minor with the victim, at any time in which the agreement between the parties referred to in Article 19 of this law occurs, will also be effective during the execution of the judgment.

Article 51, now no longer in the second but in the third subparagraph following the amendment made by the L.O. 8/2006 of 4 December 2006, in fact, provides for the possibility that the conciliation intervened between the parties can fall the measure provided for in the sentence, if it is an expression of reproach and condemnation of the conduct of the offender (unlike the provisions of the law of ' 92 ).

In this case the mediation is conceived as an alternative to the continuation of the execution of the sentence. it is rather unusual and, as regards the objectives pursued by mediation, rather useless.

Legal practitioners, in fact, consider thepreliminary examination phase of the criminal trial as the natural space of mediation, as free from prejudices and mistrust that are in the next phase of the process and they also defend mediation as a useful tool to avoid the execution of the punishment.

In the case, however, provided for by article 51.3 of the law, mediation does not prevent the child from either the criminal trial or the execution, even partial, of the punishment.

Reconciliation and remedying of damage are conceived as an out-of-court conflict resolution tool, although included in the criminal process: in the mediation foreseen in the

\footnotetext{
${ }^{14}$ With regard to the cases of mediation in the initial phase, Law 5/2000 has not made any significant change compared to the law of ' 92 . The requirements for access to mediation are basically the same in both laws.
} 


\section{Giovanna Palermo}

educational phase, the public prosecutor represents the legality on which the mediator acts, while in the cases provided for in the execution phase is the judge acting as guarantor.

A full institutionalization of mediation took place in Spain, and therefore only in the criminal trial against juvenile offenders, while for adults a "Mediation and Restorative Program in Criminal Jurisdiction" was launched in 1998 and only in Catalonia. Service of alternative criminal sanctions ".

The Barcelona Penal Mediation Office, both in the juvenile as well as adults, is physically located inside the judicial structures, where the criminal trial is breathed and the mediators are functionally inserted in the justice department. All this to underline that the mediation has not only a preventive role in the criminal policy and of the atenciò a vìctima, but it is also a possible formal instrument of social control. To reserve for penal mediation an "exo-systematic" position, in which it is an alternative to the penal system, in terms of deflation or better decriminalization in concrete terms, means giving it the function of promoting an internal rationalization of criminal law, with a view to marginalizing progressively the penalistic response to the advantage of the remaining instruments of social control. With the current tendency to give it, instead, an "endo-systematic" collocation, in which it represents a "stabilization variant" of the penal system, the mediation will end up remaining "entangled" in the regulatory tangles of the penal system and "institutionalized" as a new form of formal social control, deprived of its very essence.

In fact, the institutionalization of mediation would end up distorting it so much that it became ineffective. Indeed, mediation by its very nature is an informal process and its "forced" insertion in the judicial universe would hardly allow it to preserve its peculiarities. It is difficult to think that it could preserve that voluntary and spontaneous character that today guarantees the ability to manage the conflict in its complexity made of a manifest and a latent level, because silently the mediation would no longer present itself as a proposal but as an imposition and consequently, the refusal to start this path or its failure would end, as we have already underlined, to be sanctioned.Moreover, it would lose the characteristic of informal path that acts and moves on that emotional level that the judicial universe ignores, debased in a schematic logical-rational process, deprived of its strength and its effectiveness.

\section{CONCLUSION}

In the face of this crisis of legitimacy of criminal law and its inability to meet the needs of each individual, the community is organized by developing alternative tools of conflict management that, on the one hand, heighten the crisis of law and, on the other, tend to increase the power of the social system to function autonomously.

The weakening of expectations towards formal control tend to increase the space of informal control.

The attempt to institutionalize mediation expresses the desire for law and, therefore, for the judicial universe to absorb it to rediscover or recreate a new systemic balance and recover legitimacy, with a view to re-establishing an individual-institution interaction, to exercise control over individuals, their conflicts, on how to manage them and on the social risks of these conflicts, with a view to recovering and strengthening its legitimacy.

Mediation is open to this end because it expresses the desire and the will to deform the management procedures with a view to restoring the ownership of the conflict and its "solution" to the parties involved. 


\section{BIBLIOGRAPHY:}

- Adler P., Lovass, K., Milner, N., “The Ideologies of Mediation: The Movement's Own Stories," Law and Policy, Vol. 10, No. 4, 1988.

- Auerbach J. S., Justice Without Law? Resolving Disputes Without Lawyers, New York: Oxford University Press, 1983.

- Beristain Ipiña A., La justícia penal font de victimacions i de satisfaccions?, in "La mediació penal", Justicia i societat, Generalitat de Catalunya, 1999.

- Bisi R., Vittimologia. Dinamiche relazionali tra vittimizzazione e mediazione, Franco Angeli, 2004.

- Bonafe' Schmitt J.P., La médiation scolaire par les élèves, ESF éditeur, 2000.

- Bouchard M., La mediazione: una terza via per la giustizia penale?, in "Questione giustizia”n. 3/4, 1992.

- Bouchard M., Mediazione: dalla repressione alla rielaborazione del conflitto, tratto da "Dei delitti e delle pene" n. 2 del 1992.

- Bouchard M., Vittime e colpevoli: c'è spazio per una giustizia riparatrice?, "Questione giustizia", 4, 888, 1995.

- Bush R. B., Folger, J., The Promise of Mediation. San Francisco: JosseyBass, 1994.

- Bush R. B., Folger J., The Promise of Mediation. San Francisco: JosseyBass, 1994.

- Castillejo Manzanares R., El nuevo proceso penal: la mediación, Revista de derecho y proceso penal, 2010, núm. 23.

- Collins R., "Changing conceptions in the sociology of the professions," in R. Torstendahl and M. Burrage (eds.), The Formation of Professions: Knowledge, State and Strategy, Newbury Park: Sage Publications, 1990.

- Cruz Márquez B., La medida de internamiento y sus alternativas en el derecho penal juvenil, Madrid, Dykinson, 2007.

- Folger J., Jones T., New Directions in Mediation: Communication Research and Perspectives Newbury Park: Sage Publications, 1994.

- Gallino L., Dizionario di sociologia, UTET, Torino, 1993.

- Herman G. N., Cary J.M., Legal Counseling, Negotiating, and Mediating: A Practical Approach, V 16, Issue 3, LexisNexis, 1999.

- LeBaron M., "Mediation, Conflict Resolution and Multicultural Reality: Culturally Competent Practice," in E. Kruk, Mediation and Conflict Resolution in Social Work and the Human Sciences, Chicago: Nelson-Hall, 1997.

- Matthews R., Informal Justice? Beverly Hills: Sage Publications, 1988.

- Elena-Ana Nechita, Criminalistică. Tehnica si tactica criminalsitică, PRO Universitaria, Bucharest, 2009.

- Nugent, W., Paddock, J., Evaluating the effects of a victim-offender reconciliation program on reoffense, Research on Social Work Practice, 6, 1996.

- Nugent, W., Paddock, J., The effect of victim offender mediation on severity of Reoffense, Mediation Quarterly, 12, 1995.

- Palermo G., Prospettive socio-giuridiche della mediazione penale in Spagna, III edizione rivisitata e aggiornata, Cuam University Press, 2016.

- Picotti L., La mediazione nel sistema penale minorile, CEDAM, 1998. 


\section{Giovanna Palermo}

- Rifkin J., Millen J., Cobb S., "Toward a new discourse for mediation: A critique of neutrality,” Negotiation Journal, Vol. 9, 1991.

- Ross E. A., Social control; a survey of the foundations of order, New York, The Macmillan Company, London, Macmillan \& Co., ltd., 1901.

- Smith, B., Hillenbrand, S., Making victims whole again: Restitution, victim-offender reconciliation programs, and compensation, in R. Davis, A. Lurigio, \& W. Skogan (Eds.),Victims of crime (2nd ed.), Thousand Oaks, CA: Sage, 1997.

- Umbreit, M. S., Coates, R. B., Cross-site analysis of victim-offender mediation in four states, Crime and Delinquency, 39, 1993.

- Van Ness, D., Strong, K., Restoring justice. Cincinnati, OH: Anderson, 1997.

- Woolpert, cit. in Mackay R., Restitution and Ethics: A Sketch for an Aristotelian Theory of Restitution, 1992.

- Woolpert, S., Victim-offender reconciliation programs. In K. Duffy, J. Grosch, \& P. Olczak (Eds.), Community mediation: A handbook for practitioners and researchers, New York: Guilford, 1991.

- Wright, M., Justice for victims and offenders, Philadelphia, Open University Press, 1991.

- Zehr, H.,Changing lenses: A new focus for crime and justice, Scottsdale, PA Herald, 1990. 